\title{
IMPROVING STUDENT'S NATURALIST INTELLIGENCE THROUGH OUTDOOR ACTIVITIES ON PLANT MORPHOLOGY LEARNING
}

\author{
Lilis Lismaya \\ Department of Biology Education, Faculty of Teacher Training and Education, Universitas Kuningan, \\ Indonesia \\ E-mail: lilislismaya2017@gmail.com
}

\begin{abstract}
APA Citation: Lismaya, L. (2018). Improving student's naturalist intelligence through outdoor activities on plant morphology learning. Indonesian Journal of Learning and Instruction, 1(1), 47-52.
\end{abstract}

Received: 19-02-2018

Accepted: 26-03-2018

Published: 01-04-2018

\begin{abstract}
The purposes of this research are to analyze the improvement of students' naturalist intelligence through outdoor activities on plant morphology learning, to analyze the difference of result between pretest and posttest on plant morphology learning, and to reveal students' response to the application of plant morphology learning. The research method used is an experimental research with one-group pretest-posttest design. This study only used one experimental class given treatment to assess the effect of the treatment without comparison with the control class. The instrument used is questions of naturalist intelligence. The results of this research indicated that: 1) there is a difference result between pretest and posttest on student's naturalist intelligence before and after plant morphology learning using outdoor activities; 2) there is an improvement of students' naturalist intelligence through outdoor activities learning; and 3) positive response came from students on the application of outdoor activities learning.
\end{abstract}

Keywords: naturalist intelligence; outdoor activities; plant morphology.

\section{INTRODUCTION}

Education is not merely about how to acquire knowledge, but it is an effort to improve students' understanding, attitudes, abilities, skills and self-development. The lack abilities owned by students include their ability in classifying nature Hands-on Investigation and caring for nature. Hence, it needs a way to improve those abilities.

This ability or competence is expected to be enhanced through various learning processes at school. One of the learning process that can be used to achieve the above competencies is through Outdoor Activities. Outdoor activities is an approach done by lecturers, where lecturers invite students to study outside the classroom to see field events directly that are used as learning resources (Lazear, 2004). The role of lecturers is as a motivator, meaning that lecturers as a guide for students to learn through the experience they get.
Outdoor activities is one way how we improve students' learning capacity. Students can learn more deeply through the objects they face than if they are learning in a classroom that has many limitations. Furthermore, studying outside the classroom can help students apply their knowledge. In addition, outdoor activities are more challenging for students and bridge between theories in the book and the reality that is in the field. The quality of learning in real situations will provide increased learning achievement through the learned objects and can build better social and personal skills. Outdoor activities can be done anytime in accordance with the draft of program created by the lecturer.

\section{METHOD}

The method used in this research is weak experimental with the one-group pretest- 


\section{Lilis Lismaya}

Improving student's naturalist intelligence through outdoor activities on plant morphology learning

posttest design (Fraenkel \& Wallen, 2007).

This present study only used experimental class that is given treatment to assess the effect of the treatment, without comparing it with the control class. The research design is shown below.

Table 1. The one-group pretest-posttest research design
$\mathrm{X}$

\begin{tabular}{ccc}
\hline $\mathrm{O}$ & $\mathrm{X}$ & $\mathrm{O}$ \\
Pretest & Treatment & Posttest \\
\hline
\end{tabular}

The population in this study is all students of Biology Education, University of Kuningan, amounted to 110 students. The sample used in this research is taken using purposive sampling as much as one class at first level in second semester who are students of Biology

Department in FKIP Kuningan University with amount of 27 students who are taking course of Plant Morphology.

The instrument used is a written test in form of essays which contains indicators to measure naturalist intelligence. The test is given at the beginning and end of the learning. In addition, questionnaires are used to find out student's responses on the study of Plant Morphology through Outdoor activities. This study conducted processing and data analysis with statistical tests, and the activities include scoring for pretest and posttest, calculating Ngain, and the data analysis by using Software Statistical Package for Social Science (SPSS) for Windows version 16.0.

\section{RESULTS AND DISCUSSION}

The results of the research are presented in sequence as follows: (1) difference of result between pretest and posttest on plant morphology learning to student's naturalist intelligence, (2) improvement of student's naturalist intelligence through application of outdoor activities, and (3) student's response to the application of outdoor activities. The results of validity and reliability test of the instrument are described in Table 2 below.

Table 2. Result of validity and reliability test

\begin{tabular}{cccc}
\hline No & Statistical Test & Value & Conclusion \\
\hline 1. & Validity Test & 0.677 & High \\
2. & Reliability Test & 0.752 & High \\
\hline
\end{tabular}

The results of the test analysis that includes the validity test shows the value of 0.677 which means that all questions or items of naturalist intelligence test have high validity. Reliability test results show the value of 0.752 meaning that the overall questions of naturalist intelligence test has high category of reliability. Based on the results of validity and reliability tests, it can be concluded that the questions of naturalist intelligence can be used as an instrument in further research.

\section{Difference of result between pretest and posttest on plant morphology learning through outdoor activities}

To know the application of outdoor activities to naturalist intelligence on plant morphology learning, then it tested the results of pretest and posttest. The following shows the average results of pretest and posttest in experimental class.

Table 3. Average result of multiple intelligences pretest and posttest

\begin{tabular}{cccc}
\hline \multirow{2}{*}{ Class } & \multirow{2}{*}{ Student Total } & \multicolumn{2}{c}{ Naturalist Intelligence } \\
\cline { 3 - 4 } & & Average of Pretest & Average of Posttest \\
\hline Experimental Class & 27 & 70.52 & 74.88 \\
\hline
\end{tabular}

Table 3 shows the average of pretest score of the experimental class is 70.52. After the outdoor activities learning is conducted, the students are given a posttest to see the student's Naturalist Intelligence. Posttest results showed that students' posttest score 
achieved 74.88 with a maximum value is 80 . The results of the student's Naturalist Intelligence analysis based on the average value of pretest and posttest can also be seen in Figure 1.

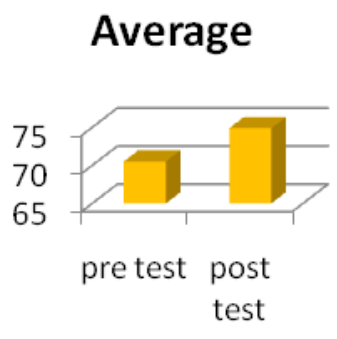

Figure 1. Average of pretest and posttest

From the results of statistical tests, the data obtained is normally distributed and homogeneous so the hypothesis testing is done by parametric statistical t-test Sample Independent Test. The t-test was conducted to determine the level of significance of experimental class differences compared to the minimum criteria of mastery learning (KKM) of Plant Morphology course. The results of the test with the t-test of naturalist intelligence can be seen in Table 4.

Table 4. T-test analysis result of naturalist intelligence

\begin{tabular}{cccccc}
\hline $\begin{array}{c}\text { Data } \\
\text { Source }\end{array}$ & Class & $\begin{array}{c}\text { Average } \\
\text { Value }\end{array}$ & Significance & $\boldsymbol{\alpha}$ & Conclusion \\
\cline { 1 - 3 } Posttest & Experimental & 73 & 0.000 & 0.05 & Difference found \\
\cline { 2 - 5 } & $K K M$ & 70 & 0.00 &
\end{tabular}

From the table, it can be seen that the result of t-test shows the significance of 0.00 $<\alpha(\alpha=0.05)$, so it can be concluded that there is a significant difference of naturalist intelligence of experimental class compared to $K K M$ of plant morphology course.

Based on the result of analysis of experimental class as a whole on t-test shows that there is a significant difference of naturalist intelligence compared to $K K M$ of Plant Morphology course. Both of them show that there is an influence of the application of outdoor activities on plant morphology learning toward students' naturalist intelligence on leaf material and plant branching patterns.

\section{The improvement of naturalist intelligence through outdoor activities}

To know the improvement of naturalist intelligence result in experimental class as a whole based on Pre-test and Post-test results, then it is calculated by using gain formula and then classified. Recapitulation of gain value calculation results are described in Table 5 below.

Table 5. Result of N-gain test

\begin{tabular}{ccc}
\hline Class & Value & Category \\
\hline Experimental & 0.4 & Medium \\
\hline
\end{tabular}

From table 5 above, it can be clearly seen that the value of gain value obtained in the experimental class as a whole is 0.4 in the medium category, meaning that the application of outdoor activities on the Plant Morphology learning can increase students' naturalist intelligence.

Next is the test of normality and homogeneity to gain value of students' naturalist intelligence. Normality and 


\section{Lilis Lismaya}

Improving student's naturalist intelligence through outdoor activities on plant morphology learning

homogeneity tests are used as a prerequisite for subsequent statistical tests. The calculation result of the gain value normality test of problem solving in experimental class is overall shown in Table 6.

Table 6. Result of gain value normality test

\begin{tabular}{cccc}
\hline Data & \multicolumn{3}{c}{ Naturalist Intelligence Test } \\
\cline { 2 - 4 } & P-value & A & Conclusion \\
\hline Gain Value & 0.30 & 0.05 & Normal \\
\hline
\end{tabular}

The test result of data normality with Kolmogorov-Smirnov obtained result of gain value in experimental class gain from normal distributed population with $\mathrm{P}$-value 0.30 bigger than $\alpha=0.05$. The result of Levene's homogeneity test of students' naturalist intelligence used $\alpha$ significance level $=0.05$ and obtained P-value as presented in Table 7.

Table 7. Result of gain value homogeneity test

\begin{tabular}{ccccc}
\hline \multirow{2}{*}{ Data } & \multirow{2}{*}{} & \multicolumn{3}{c}{ Naturalist Intelligence } \\
\cline { 3 - 5 } Gain Value & 27 & P-value & $\mathbf{A}$ & Conclusion \\
\hline
\end{tabular}

Based on Table 7, it is known that the student's Naturalist Intelligence gain value at the significance level $\alpha=0.05$ meets the criteria $P$-value $\geq \alpha=0.05$, this means that the variance of the data is homogeneous.

From the results of statistical tests, the data obtained is normally distributed and homogeneous so the hypothesis test is done by parametric statistical t-test Sample Independent Test. The t-test was conducted to find out the level of significance of the students' naturalist intelligence improvement, the result of t-test shows the significance of $0.00<\alpha(\alpha=0.05)$, so it can be concluded that there is an increase of students' naturalist intelligence after the application of outdoor activities on leaf material in morphology learning.

This naturalist intelligence includes several indicators, including: a) Classifying Nature; b) Hands-on Investigation; c) Nature Simulations; d) Caring for Nature; e) Sensitive to natural phenomena (Natural Patterns) (Lazear, 2004).

Based on the results of the researcher's analysis through the learning of Outdoor Activities, it is seen that the students' ability in classifying nature, especially the leaf types in Bungkirit City Forest has increased, it can be seen from students' posttest and LKM they use during the learning. Similarly, the ability of students in investigating both individual and group seems increasing, they look more enthusiastic in doing investigation in the open space.

Observation sheets are also used by the researcher in this naturalist intelligence assessment instrument. Based on the researcher's observation, it is seen that the students also look more care and sensitive to nature, because through this Outdoor Activities students are trained to love nature, not to destroy nature. They are also more excited about planning environmental conservation activities.

Naturalist intelligence is the intelligence possessed by individuals to the plants, animals and the surrounding natural environment. Individuals who have high naturalist intelligence will have a high interest and love for plants and animals of the universe. They will not carelessly cut down trees, they will not slaughter and torture animals, and they will also tend to keep the environment they are standing in. They will love plants, animals and the environment as they love themselves. This is a high naturalist intelligence (Lazear, 2004).

\section{Student's responses to the application of outdoor activities}

At the end of leaf material learning and plant branching patterns, the students of the 
experimental class as a whole were given questionnaires to find out their responses to the application of outdoor activities on plant morphology learning. The questionnaire made included six indicators which then was developed into several questions.
The recapitulation of the result percentage of student responses to the application of outdoor activities on plant morphology learning is shown in Figure 2.

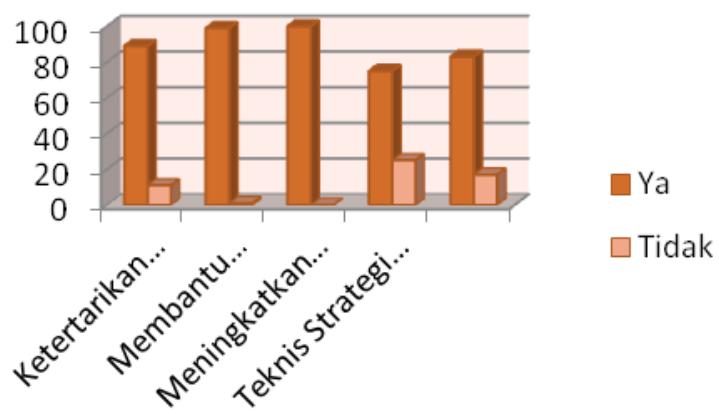

Figure 2. Result of students' response to outdoor activities

Based on Figure 2, it can be seen that almost all indicators show a positive response from students. For the indicator of interest in learning, it is seen that $83 \%$ of students answered yes and $17 \%$ answered no, meaning that most students feel interested in the application of outdoor activities on plant morphology learning. For indicators of helping students in improving interest in learning, 90\% of students stated that the application of outdoor activities can help improve their learning interest. For indicators of improving Naturalist Intelligence, it is showed that 95\% of students stated that the application of outdoor activities on plant morphology learning can improve their Naturalist Intelligence. While for indicators of increasing naturalist intelligence showed $65 \%$ of students stated that outdoor learning activities can improve their naturalist intelligence. Further, technical indicators of outdoor learning activities in the plant morphology course showed that $75 \%$ of students stated that the technical of outdoor learning activitiesis easy to understand. Therefore, from the overall students' response, it can be concluded that almost all students give a positive response to the application of outdoor learning activities on plant morphology learning.

\section{CONCLUSION}

Based on the result of the research, there are some conclusions: 1) there is a difference of result between initial or pretest and posttest on students' Naturalist Intelligence before and after plant morphology learning through Outdor Activities. This is indicated by the average calculation result of students' Pretest, Posttest and gain index. Thus, it is clearly seen that there is a significant difference between pretest and posttest results. Similarly, when the result of posttest compared to $K K M$ or Minimum Criteria of Mastery Learning, it was bigger than $K K M ; 2$ ) there is an increase in students' naturalist intelligence, especially naturalist intelligence through outdoor learning activities on plant morphology learning; and 3) students give positive responses on the application of Outdoor learning activites on plant morphology course to the improvement of students' naturalist intelligence.

Based on the findings of the research, the researcher presents the following suggestions: 1) at the time of learning, it requires good time management between each stage in outdoor learning activities and at the end of activities, it needs to strengthen the concept and principles of activities in outdoor activities and naturalist intelligence; 2) when determining the place for learning, it should be accustomed to the learning materials that will be discussed 


\section{Lilis Lismaya}

Improving student's naturalist intelligence through outdoor activities on plant morphology learning

in order to be right on target; 3) students' positive response to outdoor learning activities on the leaf concept and the plant branching pattern provides an opportunity for the use of outdoor learning activities in other biological learning concepts; and 4) some research conducted by other researchers is needed as input in this research since the possibility of differences in knowledge, how to teach and experience will affect the results of research.

\section{REFERENCES}

Anderson, L. W., \& Krathwohl, D. R. (2001). Kerangka landasan untuk pembelajaran, pengajaran dan asesmen agung prihantoro. Yogyakarta. Pustaka Pelajar.

Arends, R. I. (2008). Learning to teach ( $7^{\text {th }}$ ed.). New York: McGraw-Hill Companies.

Arikunto, S. (2007). Dasar-dasar evaluasi pendidikan. Jakarta: Bumi Aksara.

Aunurrahman. (2009). Belajar dan pembelajaran. Bandung. Alfabeta.

Brookhart, S. (2010). How to assess higher-order thingking skills in your classroom. Alexandria, Virginia. USA: ASCD.

Dahar R. W. (1996). Teori-teori belajar. Jakarta: Erlangga.

Fraenkel, J. R., \& Wallen, N. E. (2007). How to design and evaluate research in education. San Francisco: McGraw-Hill Higher Education.
Gangadevi, R. ((2014). Multiple intelligence based curriculum to enhance inclusive education to bring out human potential. International Journal of Advance Research, 2(8), 619-626.

Hamzah, A. (2009). Teori multiple intelligences dan implikasinya terhadap pengelolaan pembelajaran. Jurnal Tarbiyah Aqidah Usymuni Sumenep, 4(2), 253-260.

Hernandez, J. V. (2010). Multiple intelligences as a new paradigm in the education of Mexico. International Journal of Education, 2(1), 5-16.

Lazear, D. (2004). Higher-order thinking (The multiple intelligences way). USA: Zephyr Press.

Maftoon, S. (2012). The realization of gardner's multiple intelligences theory in second language acquisition. Journal of languange Teaching and Research, 3(6), 1233-1241.

Mousavi, S. S., \& Ahmadi, F. (2013). Education effect based on gardner multiple intelligence hypotheses in students mathematics education progress of high school second grade in Garmsar city. International Journal of Social Science (IJSS), 3(1), 25-30.

Rahmat, A. (2011). Petunjuk praktikum morfologi tumbuhan. Bandung: Pendidikan Biologi FPMIPA IKIP Bandung.

Sugiyono. (2010). Metode penelitian pendidikan pendekatan kuantitatif, kualitatif dan $R \& D$. Bandung: Alfabeta.

Tjitrosoepomo, G. (1988). Morfologi tumbuhan. Yogyakarta: Gadjah Mada University Press.

Trianto. (2007). Model-model pembelajaran inovatif berorientasi konstruktivistik. Jakarta: Prestasi Pustaka. 